\title{
Kajian Potensi Perluasan Sawah Baru di Pulau Buru Guna Mewujudkan Kawasan Strategis Pertanian Provinsi Maluku
}

\author{
Study in Expansion of New Rice Fields in Buru Island to Achieve Strategic Area of Agriculture in Maluku \\ Province
}

\section{Muhamad Akbar Anugrah $^{{ }^{*}}$, Edy Suryadi2, Robi Andoyo², Dwi Rustam Kendarto ${ }^{2}$}

\author{
${ }^{1}$ Mahasiswa Pasca Sarjana Program Studi Teknologi Agroindustri, Fakultas Teknologi Industri \\ Pertanian, Universitas Padjadjaran, Jl. Raya Bandung - Sumedang No. 21, Kabupaten Sumedang, 45363, \\ Indonesia \\ ${ }^{2}$ Staf Pengajar Fakultas Teknologi Industri Pertanian, Universitas Padjadjaran, Jl. Raya Bandung - \\ Sumedang No. 21, Kabupaten Sumedang, 45363, Indonesia \\ *E-mail: muhamad10024@mail.unpad.ac.id
}

\begin{abstract}
ABSTRAK
Provinsi Maluku merupakan daerah kepulauan yang terdiri dari 559 pulau besar dan pulau kecil. Pulau Buru merupakan salah satu Pulau Besar di Provinsi Maluku dan termasuk ke dalam gugus pulau kawasan strategis pertanian, dengan komoditas utama tanaman padi. Pemerintah Provinsi Maluku hanya mampu memenuhi sebesar 58\% kebutuhan beras di Provinsi Maluku pada tahun 2015. Pertumbuhan penduduk yang meningkat dan pergeseran pola konsumsi dari pangan lokal ke beras juga menjadi salah satu faktor perlunya melakukan peningkatan produktivitas beras di Provinsi Maluku. Peningkatan produktivitas beras bisa dilakukan, salah satunya dengan cara perluasan areal sawah baru. Tulisan ini ditujukan untuk memperoleh informasi tentang sebaran potensi calon lahan yang cocok untuk perluasan sawah baru di Pulau Buru dengan menggunakan data hasil survei lapangan yang dilakukan pada tahun 2016. Hasil pengamatan calon lahan di lapangan kemudian diolah dan dianalisis secara spasial menggunakan perangkat lunak Sistem Informasi Geografis (SIG). Hasil yang diperoleh menunjukan bahwa Pulau Buru memiliki lahan potensial seluas 13.275,82 Ha yang dikategorikan pada kelas kesesuaian lahan S3 (Sesuai Marginal), namun begitu masih sangat memungkinkan untuk dilakukan perluasan sawah baru di Pulau Buru yang berperan sebagai kawasan strategis pertanian di Provinsi Maluku.
\end{abstract}

Kata kunci: Perluasan Sawah Baru, Pertanian Kepulauan, Evaluasi Kesesuaian Lahan, Provinsi Maluku, Pulau Buru

\section{ABSTRACT}

Maluku Province is an archipelago consisting of 559 large and small islands. Buru Island is one of the big island in Maluku Province, belongs to cluster of strategic agricultural area island, with rice crops commodities. The Government of Maluku in 2015 had only supplied 58\% needed of rice in Maluku Province. Increased population growth and switched local food to rice became another factor to increased rice productivity in Maluku Province. It could be done, by the expansion of new rice fields in Maluku Province. This paper aimed to study on potential and suitable area for the expansion of new rice fields on Buru Island based on field survey data conducted in 2016. The whole data processed and analyzed spatially using GIS software. The results showed that Buru Island had a potential land area covered 13,275.82 Ha that is categorized in the S3 land suitability class (Marginally Suitable, making it possible to expand the new rice fields on Buru Island that acted as a strategic agricultural area in Maluku Province.

Keywords: Expansion new rice fields, Archipelago Agriculture, Land Suitability Evaluation, Maluku Province, Buru Island

Diterima: 19 Desember 2018; Disetujui: 30 Desember 2018

DOI : 10.24198/jt.vol12n2.2

\section{PENDAHULUAN}

Provinsi Maluku merupakan daerah kepulauan yang terdiri dari 559 pulau dan dari sejumlah pulau tersebut, terdapat beberapa pulau yang tergolong pulau besar (BPS, 2015). Pulau besar yang ada di Provinsi Maluku berjumlah 10 pulau, yaitu Pulau Wetar, Pulau Yamdena, Pulau Kola, Pulau Wokam, Pulau Kabror, Pulau Trangan, Pulau Maekor, Pulau 
Seram, Pulau Buru dan Pulau Ambon. Pulau Seram dan Pulau Buru merupakan dua pulau terbesar dengan luasan $18.625 \mathrm{~km}^{2}$ dan 9.000 $\mathrm{km}^{2}$ (BPS, 2015). Pulau Besar dan Pulau Kecil yang ada di Kepulauan Maluku terbagi menjadi 12 gugus pulau yang dikelompokan menurut letak geografis dan potensi pengembangan setiap daerahnya masing-masing (BAPPEDA, 2013). Gugus pulau itu adalah Pulau Buru, Seram Bagian Barat, Seram Utara, Seram Bagian Timur, Seram Selatan, Banda, Ambon dan PP. Lease, Kepulauan Kei, Kepulauan Aru, Tanimbar, Babar dan Kepulauan Terselatan.

Pulau Buru merupakan pulau kedua terbesar di Provinsi Maluku. Semenjak tahun 2008 Pulau Buru terbagi menjadi dua, yaitu Kabupaten Buru dan Kabupaten Buru Selatan. Kabupaten Buru Selatan berada di bagian selatan Pulau Buru, sedangkan Kabupaten Buru berada di sisi utaranya. Fungsi dan pembangunan Pulau Buru di bidang Pertanian, Kehutanan, Perkebunan, Perikanan, Pariwisata dan Peternakan (BAPPEDA, 2013). Pulau Buru juga merupakan lokasi prioritas pengembangan kawasan strategis pertanian padi sawah bersamaan dengan daerah Seram Utara, Seram Bagian Barat dan Seram Bagian Timur (Distan, 2017).

Kabupaten Buru memiliki luas baku lahan sawah seluas 7.207 ha pada tahun 2015 (BPS, 2016a). Luas sawah yang ditanami tersebut merupakan rekapitulasi dari tiga kecamatan lumbung padi yang ada di Kabupaten Buru, yaitu Kecamatan Waeapo, Kecamatan Lolong Guba dan Kecamatan Waelata. Luasan terbesar dimiliki oleh Kecamatan Waelata seluas 3.250 ha, kemudian Kecamatan Waeapo seluas 2.813 ha dan disusul oleh Kecamatan Lolong Guba seluas 1.144 ha (BPS,2016b; BPS, 2016c). Tiga lokasi ini merupakan lokasi penghasil padi sawah, selain karena topografi wilayahnya yang berupa dataran terhampar yang luas, juga termasuk kedalam daerah irigasi teknis.

Pengembangan Kawasan Strategis Pertanian di gugus Pulau Buru belum cukup optimal, hal itu terbukti dengan masih ketergantungannya Provinsi Maluku akan kebutuhan beras dari daerah lain. Ketersediaan beras di Provinsi Maluku pada tahun 2015 hanya sebesar 58\% saja (Distan, 2017). Pertambahan penduduk yang terus meningkat setiap tahunnya serta pergeseran pola konsumsi dari pangan lokal ke beras juga menjadi isu lain yang dihadapi oleh Provinsi Maluku.
Meningkatnya kebutuhan akan beras, harus diiringi dengan peningkatan produktivitas beras di Provinsi Maluku. Pertambahan luas tanam padi sawah guna meningkatkan produktivitas beras menjadi salah satu kebijakan yang harus diterapkan di gugus pulau yang dikembangkan sebagai kawasan strategis pertanian ini, karena masih banyak lahan yang belum dimanfaatkan secara optimal. Melihat hal itu, maka dilakukan penelitian yang bertujuan untuk mengetahui seberapa besar potensi calon lahan yang cocok untuk dikembangkan untuk padi sawah di Pulau Buru, berdasarkan kemampuan lahan, potensi lahan serta faktor-faktor yang menjadi pembatas. Hasil dari penelitian ini diharapkan dapat menjadi acuan dalam perluasan cetak sawah baru di Pulau Buru.

\section{METODOLOGI}

Metode yang digunakan sesuai pada Gambar 1, adalah survei lapangan, kemudian dilanjutkan dengan evaluasi kesesuaian lahan dengan mengidentifikasi kesesuaian lahan untuk tanaman padi sawah. Evaluasi lahan adalah suatu proses penilaian sumber daya lahan untuk tujuan tertentu dengan menggunakan suatu pendekatan atau cara yang sudah teruji (Ritung dkk., 2007). Hasil dari evaluasi lahan akan memberikan informasi mengenai arahan tentang penggunaan suatu lahan yang sudah dievaluasi. Informasi tersebut kemudian ditumpangsusun dengan peta lainnya untuk memperoleh luasan yang potensial sebagai daerah perluasan sawah baru di Kabupaten Buru, Provinsi Maluku.

Bahan-bahan yang dibutuhkan dalam penelitian ini diantaranya adalah batas calon lahan sawah, peta RTRW Provinsi Maluku, peta administrasi, peta jenis tanah, peta kontur, peta penggunaan lahan, peta kawasan hutan dan peta sawah eksisting.

Survei lapangan dilakukan untu k memperoleh informasi batas calon lahan sawah secara spasial dan pengamatan pada profil tanah. Pengamatan kemiringan lereng dan penggunaan lahan pada calon lahan sawah juga dilakukan untuk melakukan tinjau lapang pada peta kontur dan penggunaan lahan yang sudah ada.

Calon lahan yang sudah direncanakan kemudian diukur secara terrestrial dengan langsung mengelilinginya sesuai dengan ajuan petani atau pemilik lahan. 


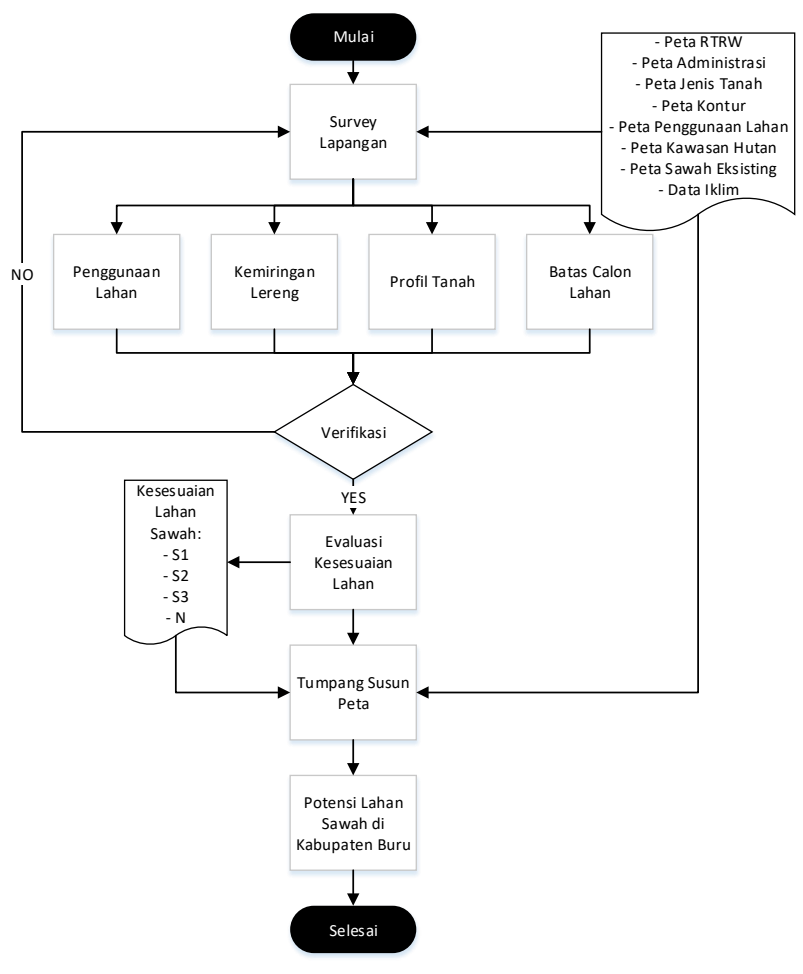

Gambar 1. Tahapan Penelitian

Pengamatan profil tanah pada calon lahan sawah dengan cara melakukan identifikasi karakteristik calon lahan yang diamati di lapangan sesuai dengan peta jenis tanah yang digunakan sebagai peta kerja. Karakteristik lahan adalah sifat lahan yang dapat diukur atau diestimasi (Djaenudin dkk., 2011). Karakterisasi lahan dilakukan pada calon lahan dengan cara pengamatan pada batas-batas calon lahan. Karakteristik lahan meliputi tanah, lingkungan dan iklim setempat kemudian dibandingkan dengan kriteria kesesuaian lahan bagi tanaman padi sawah. Hasil pengamatan di lapangan kemudian dikaji berdasarkan peta RePPProT tahun 1987. Peta RePPProT dijadikan sebagai acuan karena, terlepas dari kekurangannya, peta sistem lahan RePPProT merupakan satu-satunya peta tematik bentuk lahan yang terlengkap di Indonesia (Nurwadjedi, 2000). Sistem lahan tersebut kemudian dijadikan acuan dalam pembuatan satuan peta tanah pada lokasi calon lahan padi sawah di Pulau Buru. Calon lahan yang ada di Pulau Buru dibedakan menjadi 12 satuan peta tanah sesuai dengan data yang tercantum pada Tabel 1.

Pengamatan tanah dilakukan melalui pemboran atau profil tanah sedalam 1,2 meter atau lebih dangkal apabila terdapat batuan kukuh untuk tanah mineral, sedangkan pada tanah gambut sampai kedalaman 1,5 meter jika ketebalan gambut kurang dari 1 meter atau substratum (tanah mineral) jika ketebalan gambut lebih atau sama dengan 1 meter.

Informasi lapangan tersebut kemudian digunakan untuk melakukan evaluasi kesesuaian lahan. Metode evaluasi lahan mengacu pada Petunjuk Teknis Evaluasi Lahan untuk Komoditas Pertanian (Djaenudin dkk., 2011) dengan modifikasi sesuai kondisi setempat. Hasil evaluasi lahan kemudian disandingkan dengan kelas kesesuaian lahan yang mengacu pada kerangka FAO (1976) sebagai berikut:

\begin{tabular}{ll}
\hline \multirow{2}{*}{ Kelas S1: } & Sangat sesuai: Lahan tidak mempunyai \\
& faktor pembatas yang berarti atau nyata \\
& terhadap penggunaan secara \\
& berkelanjutan, atau faktor pembatas \\
& bersifat minor dan tidak akan \\
& berpengaruh terhadap produktivitas \\
& lahan secara nyata.
\end{tabular}

Cukup sesuai: Lahan mempunyai faktor Kelas S2: pembatas, dan faktor pembatas ini akan berpengaruh terhadap produktivitasnya, memerlukan tambahan masukan (input). Pembatas tersebut biasanya dapat diatasi oleh petani sendiri Kelas S3: pembatas yang berat, dan faktor pembatas ini akan sangat berpengaruh terhadap produktivitasnya, memerlukan tambahan masukan yang lebih banyak daripada lahan yang tergolong S2. Untuk mengatasi faktor pembatas pada S3 memerlukan modal tinggi, sehingga perlu adanya bantuan atau campur tangan (intervensi) pemerintah atau pihak swasta.

Tidak Sesuai: Lahan mempunyai faktor pembatas yang sangat berat dan/atau sulit diatasi.

Hasil evaluasi kesesuaian lahan kemudian ditumpangsusunkan dengan menggunakan perangkat lunak SIG pada peta RTRW Provinsi Maluku, peta administrasi, peta kawasan hutan dan peta sawah eksisting. Lokasi calon lahan sawah kemudian dikategorisasi apakah termasuk kedalam kelas S1, S2, S3 atau N berdasarkan kesesuaian lahan untuk tanaman sawah.

\section{HASIL DAN PEMBAHASAN}

\section{Survei Batas Calon Lahan}

Kegiatan survei batas calon lahan merupakan tahap awal dalam kegiatan perluasan sawah baru. Survei batas calon lahan dimulai dengan melakukan pengukuran secara terrestrial pada calon lahan yang akan dikembangkan menjadi lahan padi sawah. Informasi mengenai 
calon lahan yang akan dikembangkan menjadi lahan padi sawah diperoleh dari instansi setempat yang dipadukan dengan data hasil tumpangsusun peta RTRW, peta administrasi, peta jenis tanah, peta kontur, peta penggunaan lahan, peta kawasan hutan dan peta sawah eksisting untuk daerah yang cocok untuk dikembangkan menjadi lahan padi sawah. Calon lahan bisa juga merupakan ajuan langsung dari kepala desa, kepala adat maupun para pemilik lahan.

Hasil pengukuran calon lahan di Pulau Buru mencapai 16.018,03 ha. Luasan tersebut berada di dua kabupaten, yaitu Kabupaten Buru seluas $15.858,96$ ha dan Kabupaten Buru Selatan seluas 159,07 ha. Distribusi luasan pada Tabel 2 menunjukan bahwa Kecamatan Waeapo, Kecamatan Lolong Guba dan Kecamatan Waelata memiliki luasan calon lahan padi sawah yang paling besar. Kecamatan Waeapo, Kecamatan Lolong Guba dan Kecamatan Waelata sebagai lumbung padi di Kabupaten Buru menyumbang luasan calon lahan sampai 74\% dari seluruh calon lahan yang ada di Pulau Buru.

Tabel 1. Satuan Peta Tanah Calon Lahan di Pulau Buru

\begin{tabular}{|c|c|c|c|c|c|}
\hline No. SPT & Uraian & $\begin{array}{l}\text { Lereng } \\
(\%)\end{array}$ & Bentuk Wilayah & Fisiografi & Bahan Induk \\
\hline 1 & $\begin{array}{l}\text { Tropaquepts, Tekstur sedang, } \\
\text { Drainase terhambat sampai } \\
\text { sangat terhambat }\end{array}$ & $0-3$ & Datar & $\begin{array}{l}\text { Dataran Aluvial baik berupa endapan } \\
\text { sungai, kipas aluvial, maupun dasar } \\
\text { lembah sempit }\end{array}$ & Alluvium \\
\hline 2 & $\begin{array}{l}\text { Tropofluvents, Tekstur sedang, } \\
\text { Drainase sedang }\end{array}$ & $0-3$ & Datar & Jalur meander sungai & Alluvium \\
\hline 3 & $\begin{array}{l}\text { Tropopsamments, Tekstur kasar, } \\
\text { Drainase baik }\end{array}$ & $0-3$ & Datar & Jalur meander sungai & Alluvium \\
\hline 4 & $\begin{array}{l}\text { Eutrudepts, Tekstur sedang, } \\
\text { Drainase sedang }\end{array}$ & $0-3$ & Datar & $\begin{array}{l}\text { Dataran Aluvial baik berupa endapan } \\
\text { sungai, kipas aluvial maupun dasar } \\
\text { lembah sempit }\end{array}$ & Alluvium \\
\hline 5 & $\begin{array}{l}\text { Dystrudepts, Tekstur sedang, } \\
\text { Drainase sedang }\end{array}$ & $0-3$ & Datar & Dataran Aluvial & Alluvium \\
\hline 6 & $\begin{array}{l}\text { Tropopsamments, Tekstur kasar, } \\
\text { Drainase cepat }\end{array}$ & $4-8$ & Berombak & Jalur meander sungai & Alluvium \\
\hline 7 & $\begin{array}{l}\text { Eutrudepts, Tekstur sedang, } \\
\text { Drainase sedang }\end{array}$ & $4-8$ & Berombak & $\begin{array}{l}\text { Dataran Aluvial baik berupa endapan } \\
\text { sungai, kipas aluvial maupun dasar } \\
\text { lembah sempit, biasanya dibawah } \\
\text { bukit karstik }\end{array}$ & Alluvium \\
\hline 8 & $\begin{array}{l}\text { Dystrudepts, Tekstur sedang, } \\
\text { Drainase sedang }\end{array}$ & $4-8$ & Berombak & $\begin{array}{l}\text { Dataran Aluvial dibawah perbukitan } \\
\text { non-karstik }\end{array}$ & Alluvium \\
\hline 9 & $\begin{array}{l}\text { Halpludalfs, Tekstur sedang } \\
\text { sampai halus, Drainase baik }\end{array}$ & $9-15$ & Bergelombang & Dataran karstik bergelombang & $\begin{array}{l}\text { Batu gamping } \\
\text { dan Batu pasir }\end{array}$ \\
\hline 10 & $\begin{array}{l}\text { Hapludults, Tekstur sedang } \\
\text { sampai halus, Drainase baik }\end{array}$ & $9-15$ & Bergelombang & Dataran bergelombang & $\begin{array}{l}\text { Batu liat dan } \\
\text { Batu pasir }\end{array}$ \\
\hline 11 & $\begin{array}{l}\text { Halpludalfs, Tekstur sedang } \\
\text { sampai halus, Drainase baik }\end{array}$ & $16-25$ & Berbukit & Perbukitan karstik & $\begin{array}{l}\text { Batu gamping } \\
\text { dan Batu pasir }\end{array}$ \\
\hline 12 & $\begin{array}{l}\text { Hapludults, Tekstur sedang } \\
\text { sampai halus, Drainase baik }\end{array}$ & $16-25$ & Berbukit & Perbukitan Sedimen & $\begin{array}{l}\text { Batu liat dan } \\
\text { Batu pasir }\end{array}$ \\
\hline
\end{tabular}




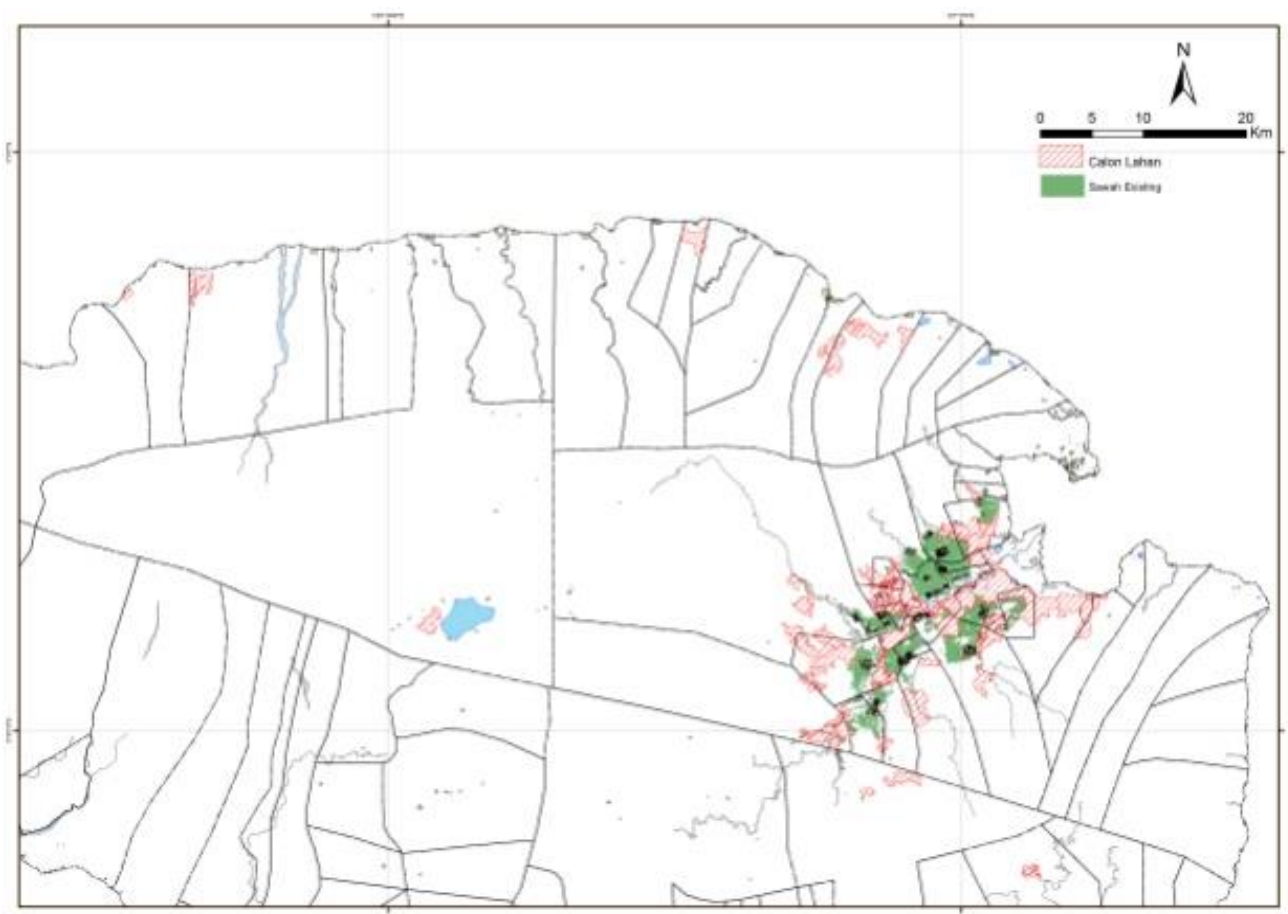

Gambar 1. Sistem dan Distribusi Calon Lahan Padi Sawah di Pulau Buru

Warna merah dengan garis miring pada Gambar 2 menunjukan sebaran calon lahan padi sawah di Pulau Buru. Distribusi calon lahan padi sawah di dominasi oleh Kabupaten Buru yang berpusat di Dataran Waeapo yang terdiri dari tiga kecamatan yaitu Kecamatan Waeapo, Kecamatan Waelata dan Lolong Guba. Calon lahan berada tidak jauh dari sawah eksisting yang ditunjukan oleh warna hijau pada Gambar 2, karena selain sudah ada jaringan irigasi, kondisi ekologis di daerah tersebut terbukti cocok untuk dikembangkan menjadi lahan padi sawah.

Tabel 2. Luasan Hasil Pengukuran Calon Lahan untuk Perluasan Sawah Baru di Pulau Buru

\begin{tabular}{llr}
\hline Kabupaten & Kecamatan & $\begin{array}{c}\text { Luas Calon Sawah } \\
(\mathrm{Ha})\end{array}$ \\
\hline \multirow{3}{*}{ Buru } & Waeapo & $1.562,67$ \\
& Lolong Guba & $4.935,12$ \\
& Waelata & $5.412,82$ \\
& Air Buaya & 474,62 \\
& Fena Leisela & 674,99 \\
& Kayeli & $1.049,01$ \\
& Lilialy & 695,61 \\
\hline \multirow{3}{*}{ Buru Selatan } & & $1.024,10$ \\
& Waplau & 150,07 \\
\hline
\end{tabular}

Menurut Dinas Pertanian Kabupaten Buru Selatan, kabupaten tersebut yang merupakan Kabupaten Baru di Provinsi Maluku sedang mencoba membuka kawasan strategis pertanian padi sawah di daerahnya. Calon lahan di Kabupaten Buru Selatan merupakan lahan milik petuanan adat yang dihibahkan untuk dikembangkan menjadi lahan pertanian padi sawah. Calon lahan berada di sepanjang aliran Sungai Wae Poli di Kecamatan Waesama, dengan luasan 159,07 ha. Calon lahan hanya pernah ditanami padi ladang, karena meskipun berada di sepanjang jalur sungai, namun belum ada jaringan irigasi.

\section{Identifikasi Karakteristik Lahan}

Berdasarkan identifikasi karakteristik lahan pada Tabel 3, dapat dijumpai 5 (lima) sistem lahan pada calon lahan di Pulau Buru, yaitu Orai (ORI), Kuri (KRI), Sapauwar (SPW), Bobot (BOB) dan Ayata (AYT) yang tersebar di Kabupaten Buru dan Kabupaten Buru Selatan.

Konsep sistem lahan diperkenalkan oleh Christian dan Stewart (1968) dengan didasarkan pada prinsip ekologi dengan mengganggap ada hubungan yang erat antara tipe batuan, hidroklimat, landform, tanah dan organisme. Tabel 3 menunjukan bahwa calon lahan di dominasi oleh sistem lahan Orai (ORI) dan Sapauwar (SPW). Sistem lahan tersebut mendominasi sebagian besar calon lahan yang ada di beberapa kecamatan di Pulau Buru.

Sistem lahan Orai (ORI) dan Sapauwar (SPW) memiliki fisiografi berupa dataran pada endapan muara atau sungai dan jalur meander sungai-sungai besar atau dataran pantai. Kedua sistem lahan tersebut memperlihatkan bahwa calon lahan berada di daerah yang dipengaruhi oleh sungai dan aktivitas air lainnya. Areal yang tergenang oleh air atau dipengaruhi oleh 
aktivitas air di sekitarnya merupakan daerah yang cocok untuk tumbuh tanaman padi sawah.

Satuan peta tanah dibuat untuk mengelompokkan karakterisitik tanah yang homogen agar pengelolaan lahan lebih terarah. Batas-batas satuan peta tanah ini didelineasi berdasarkan pada jenis tanah dan unsur-unsur satuan peta tanah lainnya, seperti : fisiografi, lereng, bentuk wilayah, bahan induk serta sifatsifat tambahan lainnya seperti kedalaman efektif dan drainase. Seluruh calon lahan di Kabupaten Buru tersusun dari SPT 1 sampai SPT 12, sedangkan calon lahan di Kabupaten Buru Selatan terdiri dari SPT 6, 10 dan 12.
Penilaian pada calon lahan dilakukan sampai pada tingkat subkelas. Subkelas adalah tingkatan dalam kelas kesesuaian lahan (Ritung dkk., 2007). Simbol kelas kesesuaian lahan pada calon lahan yang ada di Pulau Buru akan didampingi oleh simbol-simbol yang menjadi faktor penghambat pada kelas kesesuaian lahan yang bersangkutan. Parameternya merupakan kualitas lahan dan karakteristik lahan pada lokasi yang dilakukan pengamatan. Simbol-simbol subkelas itu juga bisa menjadi arahan untuk mengembangkan status lahan dari aktual menjadi potensial.

Tabel 3. Sistem Lahan pada Calon Lahan di Pulau Buru

\begin{tabular}{|c|c|c|c|}
\hline Simbol & Fisiografi & Jenis Tanah & Sebaran di Pulau Buru (Kecamatan) \\
\hline ORI & $\begin{array}{l}\text { Dataran Gabungan Endapan Muara dan } \\
\text { Endapan Sungai }\end{array}$ & Tropaquepts; Fluvaquents & $\begin{array}{l}\text { Lilialy, Waeapo, Lolong Guba, Waelata, } \\
\text { Kayeli }\end{array}$ \\
\hline $\mathrm{KRI}$ & $\begin{array}{l}\text { Dataran Aluvial di Pedalaman yang } \\
\text { Berteras dan Berawa }\end{array}$ & $\begin{array}{l}\text { Eutropepts; Tropaquepts; } \\
\text { Tropudalfs }\end{array}$ & Fena Leisela, Waplau \\
\hline SPW & $\begin{array}{l}\text { Jalur Meander Sungai-Sungai Besar } \\
\text { pada Dataran Pantai }\end{array}$ & Tropaquepts; Tropofluvents & $\begin{array}{l}\text { Fena Leisela, Lolong Guba, Waeapo, } \\
\text { Waelata, Waesama }\end{array}$ \\
\hline $\mathrm{BOB}$ & $\begin{array}{l}\text { Kipas Aluvial Non-Vulkanik yang } \\
\text { Melereng Landai }\end{array}$ & $\begin{array}{l}\text { Tropaquepts; Tropofluvents; } \\
\text { Fluvaquents }\end{array}$ & Air Buaya \\
\hline AYT & Dataran Karstik yang Berombak & $\begin{array}{l}\text { Rendolls; Eutropepts; } \\
\text { Tropudalfs }\end{array}$ & Lilialy, Waplau \\
\hline
\end{tabular}

Tabel 4. Kelas Kesesuaian Tanaman Padi Sawah di Pulau Buru

\begin{tabular}{|c|c|c|c|c|c|}
\hline \multirow{2}{*}{ No. SPT } & \multicolumn{2}{|c|}{ Kelas Kesesuaian Lahan } & \multirow{2}{*}{ Faktor Penghambat } & \multirow{2}{*}{ Input Dianjurkan } & \multirow{2}{*}{ Rekomendasi } \\
\hline & Aktual & Potensial & & & \\
\hline 1,2 & S3nb & $\mathrm{S} 2$ & Ketersediaan Hara, Bahaya Banjir & $\begin{array}{c}\text { Pemupukan, Saluran } \\
\text { Drainase }\end{array}$ & Padi Sawah \\
\hline 4,5 & S3n & $\mathrm{S} 2$ & Ketersediaan Hara & Pemupukan & Padi Sawah \\
\hline 7,8 & S3ns & $\mathrm{S} 2$ & Ketersediaan Hara, Lereng $4-8 \%$ & Pemupukan, Terasering & Padi Sawah \\
\hline $9,10,11,12$ & Ns & $\mathrm{N}$ & Lereng $9-25 \%$ & & $\begin{array}{l}\text { Tanaman } \\
\text { Tahunan }\end{array}$ \\
\hline 3,6 & $\mathrm{Nr}$ & $\mathrm{N}$ & Tekstur Pasir & & $\begin{array}{c}\text { Daerah } \\
\text { Konservasi }\end{array}$ \\
\hline
\end{tabular}

Tabel 5 Luasan Potensi Calon Lahan Padi Sawah di Pulau Buru

\begin{tabular}{|c|c|c|c|}
\hline Kabupaten & Kecamatan & Pengukuran Calon Lahan (Ha) & Luasan Potensi Calon Lahan (Ha) \\
\hline \multirow{7}{*}{ Buru } & Waeapo & $1.591,67$ & $1.568,13$ \\
\hline & Lolong Guba & $4.935,12$ & $4.097,63$ \\
\hline & Waelata & $5.412,82$ & $4.638,75$ \\
\hline & Air Buaya & 474,62 & 383,06 \\
\hline & Fena Leisela & 674,99 & 526,08 \\
\hline & Kayeli & $1.049,01$ & 826,97 \\
\hline & Lilialy & 695,61 & 614,70 \\
\hline \multirow{2}{*}{$\begin{array}{c}\text { Buru } \\
\text { Selatan }\end{array}$} & Waplau & $1.024,10$ & 620,50 \\
\hline & Waesama & 159,07 & - \\
\hline
\end{tabular}


Simbol-simbol sebagai parameter yang menjadi pembatas pada calon lahan yang ada di Pulau Buru diantaranya adalah :

$r=$ kondisi perakaran (tekstur, kedalaman efektif tanah dan drainase)

$\mathrm{s}=$ medan / terrain (kemiringan lahan/slope (\%), relief dan batuan permukaan)

$b=$ bahaya banjir

$\mathrm{n}=$ hara tersedia

Secara umum kondisi calon lahan di Pulau Buru pada pembatas media perakaran adalah drainase yang sedang sampai baik, bahkan di beberapa lokasi termasuk kedalam kategori cepat. Tanaman padi sawah memiliki syarat tumbuh ideal berupa drainase yang terhambat (Djaenudin dkk., 2011). Pembatas yang lain yaitu ketersediaan hara / retensi hara yang berkaitan dengan $\mathrm{pH}$ tanah yang masam. Beberapa lokasi pada calon lahan yang memiliki $\mathrm{pH}$ masam mengindikasikan tanah tersebut memiliki ketersediaan hara / retensi hara yang rendah. Tanah yang masam memiliki unsur hara mikro yang tinggi daripada unsur makro, sementara unsur hara mikro sangat sedikit dibutuhkan oleh tanaman (Amirulloh dan Prabowo, 2017). Bahaya banjir pada calon lahan di Pulau Buru tidak menjadi faktor pembatas yang fatal, dikarenakan banjir yang terjadi merupakan banjir tahunan dan jarang terjadi. Faktor pembatas yang terakhir merupakan kemiringan lereng di setiap calon lahan. Syarat tumbuh tanaman padi sawah adalah kemiringan lereng dengan nilai dibawah 8\% (Djaenudin dkk, 2011). Beberapa calon lahan yang tergolong dalam SPT 9 sampai dengan SPT 12 memiliki kemiringan lereng antara $9-25 \%$. Kondisi medan tersebut tentu menjadi pembatas bagi syarat tumbuh tanaman padi sawah, karena akan meningkatkan erosivitas di daerah tersebut.

\section{Kawasan Strategis Pertanian Pulau Buru}

Pulau Buru termasuk kedalam gugus pulau pengembangan pertanian di Provinsi Maluku, maka dari itu kebijakan dan arah pengembangan daerahnya pun harus difokuskan dalam bidang pertanian. Survei, investigasi dan pengamatan lapangan pada tahun 2016 di Pulau Buru mencatat seluas $16.018,03$ ha calon lahan merupakan lahan yang diajukan dan diproyeksikan menjadi tanaman padi sawah. Setelah dilakukan kajian dan evaluasi lahan dengan beberapa faktor pembatas bagi syarat tumbuh tanaman padi sawah yang ada di Pulau Buru, Kabupaten Buru memiliki potensi lahan untuk dilakukan perluasan sawah baru seluas
13.275,82 ha. Berbeda dengan Kabupaten Buru Selatan, dari luas yang diproyeksikan sebesar 159,07 ha, tidak ada yang cocok untuk dijadikan sebagai areal pengembangan sawah baru.

Faktor pembatas yang menyebabkan tidak cocoknya calon lahan di Kabupaten Buru Selatan adalah kemiringan lereng yang melebihi syarat tumbuh tanaman padi sawah sebesar $8 \%$ serta media perakarannya yang memiliki drainase sedang sampai baik. Distribusi luasan potensial calon lahan padi sawah setiap kecamatan yang ada di Pulau Buru pada Tabel 5 menunjukan adanya luasan yang dieliminir karena terbatas oleh 4 faktor pembatas pada evaluasi kesesuaian lahan di semua calon lahan. Luas calon lahan yang tidak sesuai di Kecamatan Waelata mencapai 800 ha dari proyeksi semula. Meskipun begitu, Kecamatan Waelata masih berada di tingkat pertama dalam pemenuhan calon lahan untuk perluasan sawah baru di Pulau Buru dengan luasan 4.638,75 ha.

Produksi beras Provinsi Maluku pada tahun 2015 adalah sebesar 70.674 ton (Distan, 2017). Angka itu masih jauh dibawah nilai kebutuhan beras di Provinsi Maluku, yaitu sebesar 121.493 ton. Provinsi Maluku pada tahun 2015 hanya bisa memenuhi $58 \%$ dari total kebutuhan beras Provinsi Maluku (Distan, 2017). Dinas Pertanian Provinsi Maluku memproyeksikan angka kebutuhan beras pada tahun 2019 mencapai 135.764 ton dan target produksi guna memenuhi kebutuhan beras pada tahun 2019 sebesar 145.200 ton dengan persentase ketersediaan beras sebesar 100\% (Distan, 2017).

Produktivitas beras Provinsi Maluku pada tahun 2016 adalah sebesar 4,9 ton GKG/Ha (Distan, 2017). Mengacu pada kajian Hassan (2014) tentang rendemen beras pada berbagai jenis varietas, bahwa rendemen beras berkisar diantara 66,60 - 76,07\%, maka rendemen dari produktivitas padi sawah pada tahun 2016 di Provinsi Maluku jika digunakan persentase rendemen sebesar $65 \%$, yaitu 4,9 ton GKG * $65 \%$ $=3,185$ ton $/ \mathrm{Ha}$. Pulau Buru sebagai salah satu kawasan strategis pertanian di Provinsi Maluku akan menyumbang sebesar $42.283,49$ ton/ $\mathrm{Ha}$ atau memberikan kontribusi tambahan sebesar 30\% dari target produksi tahun 2019 pada total produksi beras Provinsi Maluku saat calon lahan potensial di Pulau Buru direalisasikan menjadi areal sawah baru. 


\section{KESIMPULAN}

Berdasarkan hasil evaluasi kesesuaian lahan pada calon lahan di Pulau Buru, terdapat seluas 13.275,82 ha lahan potensial untuk dikembangkan menjadi lahan padi sawah di Pulau Buru. Calon lahan tersebut berada pada wilayah administrasi Kabupaten Buru, yang didominasi oleh Kecamatan Waeapo, Kecamatan Lolong Guba dan Kecamatan Waelata yang merupakan daerah lumbung padi Kabupaten Buru. Calon lahan yang berpotensi untuk dikembangkan menjadi lahan sawah baru terkategori dalam kelas S3 pada kesesuaian lahan aktual, dengan faktor pembatas berupa ketersediaan hara, kemiringan lereng dan bahaya banjir. Pulau Buru yang termasuk dalam gugus pulau kawasan strategis pertanian di Provinsi Maluku memiliki potensi yang sangat besar dalam upaya pemenuhan pangan Provinsi Maluku, dengan proyeksi kontribusi sebesar 42.283,49 ton/Ha atau sekitar 30\% dari target produksi beras pada tahun 2019 di Provinsi Maluku.

\section{UCAPAN TERIMAKASIH}

Penulis mengucapkan terima kasih kepada Dinas Pertanian Provinsi Maluku yang telah membiayai penelitian melalui skema kerjasama Pemerintah Daerah dengan Fakultas Teknologi Industri Pertanian, serta mengizinkan untuk mempublikasi hasil penelitian ini.

\section{DAFTAR PUSTAKA}

Amirrullah, J., A. Prabowo. 2017. Dampak Keasaman Tanah Terhadap Ketersediaan Unsur Hara Fosfor di Lahan Rawa Pasang Surut Kabupaten Banyuasin. Prosiding Seminar Nasional Lahan Suboptimal 2017: Palembang.

BAPPEDA Provinsi Maluku. 2013. RPJMD Provinsi Maluku Tahun 2014-2019. Pemerintah Provinsi Maluku, Ambon.

BPS Provinsi Maluku. 2015. Maluku dalam Angka 2015. Badan Pusat Statistik Provinsi Maluku, Ambon.

BPS Kabupaten Buru. 2016a. Buru dalam Angka 2016. Badan Pusat Statistik Kabupaten Buru, Namlea.
BPS Kabupaten Buru. 2016b. Statistik Kecamatan Waeapo 2016. Badan Pusat Statistik Kabupaten Buru, Namlea.

BPS Kabupaten Buru. 2016c. Statistik Kecamatan Waelata 2016. Badan Pusat Statistik Kabupaten Buru, Namlea.

BPS Kabupaten Buru. 2016d. Statistik Kecamatan Lolong Guba 2016. Badan Pusat Statistik Kabupaten Buru, Namlea.

Christian, C.S., C.A Stewart. 1968. Methodology of Integrated Surveys. In. Aerial Surveys Integrated Studie. Proc. UNESCO Conference on Principles and Methods of Integrating Aerial Surveys of Natural Resources for Development, 21-25 September 1964, Toulouse, France.

Dinas Pertanian Provinsi Maluku. 2017. Pemetaan dan Desain Cetak Sawah Baru di Maluku. Paparan Kepala Dinas Pertanian Provinsi Maluku pada Persentase Hasil Pemetaan dan Desain Cetak Sawah Baru Maluku, Ambon.

Djaenudin, D., Marwan, H. Subagjo, H., dan A. Hidayat. 2011. Petunjuk Teknis Evaluasi Lahan Untuk Komoditas Pertanian. Balai Besar Litbang sumberdaya Lahan Pertanian, Badan Litbang Pertanian, Bogor. $36 \mathrm{p}$.

FAO. 1976. Framework for Land Evaluation, Soil Resources Management and Conservation Service Land and Water Development Division. FAO Soil Bulletin No.32. FAOUNO. Rome

Hassan, Z.H. 2014. Kajian Rendemen dan Mutu Giling Beras di Kabupaten Kotabaru Provinsi Kalimantan Selatan. PANGAN, Vol. 23 No. 3 September 2014 : 232-243.

Nurwadjedi. 2000. Klasifikasi Bentuk Lahan Semi Detil (Skala 1:50.000 / 1:25.000) Hasil Pengembangan Peta RePPProT Skala 1:250.000, Globe Volume 2 No. 2, 72-83.

Ritung S, Wahyunto, Agus F, Hidayat H. 2007. Panduan Evaluasi Kesesuaian Lahan dengan Contoh Peta Arahan Penggunaan Lahan Kabupaten Aceh Barat. Balai Penelitian Tanah dan World Agroforestry Centre (ICRAF), Bogor, Indonesia. 